\title{
Examining the students' assessment and evaluation course success as per their demographic characteristics
}

\author{
D.Bahar Şahin ${ }^{1 \mathrm{a}}$ and Fazilet Taşdemir ${ }^{1}$ \\ ${ }^{1}$ Faculty of Educational, Recep Tayyip Erdoğan University, 53200, Rize, Turkey
}

\begin{abstract}
The purpose of this study is to determine whether the assessment and evaluation course success of 3 rd grade university students change significantly or not as per department, average academic success and time of preparation for the exams. The research is a relational scanning type of research which is included among scanning models. 561 3rd grade university students studying at Recep Tayyip Erdogan University within the academic year of 2013-2014 are consisting the study group of the research. During the data collection phase, success tests and "personal information" form developed by the researchers was used. The data obtained from the students was examined using the factorial ANOVA analysis technique for unrelated samples. In the analysis, assessment and evaluation course success consists the dependent variable, and department, academic average and time of preparation for the exams consist the independent variable. In the research, it was found that the common effect of independent variables on the dependent variable was significant, and post-hoc multiple comparison test was applied in order examine among which groups the differentiation in subject arises from.
\end{abstract}

Keywords: assessment and evaluation course scores; academic success; depertmans; preparation for the exam

\section{Introduction}

Today, teaching is the leading profession among the ones requiring specialized knowledge and skills despite its place and prestige differs as per the country and culture. The teaching profession, along with being a learned profession, courses on information on area of teaching profession are very important in the education of teachers.

The countries giving priority to contemporary implementations in educational programs had focused on raising equipped individuals, and within this frame they had attached great importance to assessment and evaluation. In faculties of education, the assessment and

\footnotetext{
${ }^{a}$ Corresponding author: bahar.sahin@erdogan.edu.tr
} 
evaluation course -among the basic area of profession competencies- had gained its current form as an independent course in all the departments.

One of the significant domains of assessment and evaluation in education is to assess the school learning of students in a specific time frame. The main purpose of exams and intraclass events -being implemented in school learning- is to assess and evaluate the academic success of students. In deciding the success of student, variables such as beliefs, values and attitudes of teachers, families and students, school's policy and intraclass evaluation types etc have important place. Thus, if the factors effecting the success of student will be tested, the effect of both individual variables and of the variables of class or school should be considered. There are studies intended to examine the effect of intraclass and out-of-class environmental properties on the success of students. In these researches, the variables providing and not providing advantage to academic success had been tried to be determined considering the characteristics of students. When the results of research were reviewed, it had been observed that it would be possible to determine what the students are able to do and to estimate what they can do by evaluating all the characteristics of students in order to make a healthy decision regarding the performance of students.

In this study, it was intended to determine whether the assessment and evaluation course success of 3rd grade university students change significantly or not as per department, average academic success and time of preparation for the exams. In the direction of this general purpose, answer for the question of 'Does the students' assessment and evaluation course success show significant difference as per departments, average academic success, time of preparation for the exams and interaction of these variables?" was sought.

\section{Method}

The research was performed in order to determine whether the assessment and evaluation course success of prospective teachers change or not as per their demographic characteristics. Thus, along with being an identification study, it is within the scope of a relational research due to applying to (interpretative) methods inferring from descriptive values. Relational researches are the ones in which the relation in between two or more variables is being examined without interfering these variables in any manner.

\subsection{Participants}

During the determination of research group, proper sampling method -among non-random sampling methods- was used. $5613^{\text {rd }}$ grade university students studying at Recep Tayyip Erdogan University Faculty of Education within the academic year of 2013-2014 consist the research group

\subsection{Procedure}

In the direction of the purpose of research, assessment and evaluation success test of 33 questions and personal information form were used. The validity and reliability analyses of the developed success test were performed. For the validity of scope, the weight of subjects on the table of specifications was determined and expert opinion was obtained. 33 questions, as having at least one question for each gain, were prepared. Test-retest reliability coefficient was found as $\mathrm{r}=0.81$. The article analyses of the test, which was found to have high level of stability coefficient, were also performed. In the article analysis, it was found that the lowest and highest values of difficulty and distinctiveness indices of the 
articles of assessment and evaluation test was changing respectively in between $\mathbf{p}_{\mathbf{j}}=0.14$ 0.87 and $\mathbf{r}_{\mathbf{j} \mathbf{x}}=0.32-0.44$. The assessment and evaluation success test -whose validity and reliability was determined- was applied to 3rd grade university students, and the scores gained by the students had consisted the students' data used in the research. Academic success grade point averages were obtained from the registrar's office of the relevant university.

\section{Statistical analysis}

The data obtained from the students was examined using the factoral ANOVA analysis technique for unrelated samples. In the analysis, assessment and evaluation course success consists the dependant variable, and department, academic average and time of preparation for the exams (last day, regular, listening during course) consist the independent variable. In the research, it was found that the common effect of independent variables on the dependant variable was significant, and post-hoc multiple comparison test was applied in order examine among which groups the differentiation in subject arises from.

It was determined that the assessment and evaluation course successes of prospective teachers show significant difference as per department (class, religious culture, mathematics tutorhood), averages of academic success (low, mid, high), state of preparing for the exam (last day, regular, listening during course), and that the common effect of these variables is significant $\left(\mathrm{F}_{(3,541)}=265.964, \mathrm{p}<.05\right)$

Table 1. ANOVA Results of Assessment and Evaluation Course Scores as per Department, Average Academic Success and Time of Preparation for the Exams

\begin{tabular}{llllll}
\hline Source & $\begin{array}{l}\text { TypeIII } \\
\text { Sum of } \\
\text { Sguares }\end{array}$ & df & $\begin{array}{l}\text { Mean } \\
\text { Square }\end{array}$ & F & p \\
\hline Academic Success & 6663.13 & 2 & 3331,556 & 43.025 & .000 \\
Depertment & 763.646 & 1 & 763.646 & 9.862 & .002 \\
Preparation for the Exams & 670.553 & 2 & 335.277 & 4.330 & .014 \\
AxD & 472,435 & 2 & 236,217 & 3.051 & $.048^{*}$ \\
AxP & 627,405 & 4 & 156.851 & 2.026 & .089 \\
DxP & 836,931 & 2 & 418.466 & 5.404 & $.005^{*}$ \\
AxDxP & 797,891 & 3 & 265.964 & 3.435 & $.017^{*}$ \\
& & & & & \\
Error & 41890.816 & 541 & 77.432 & & \\
\hline Corrected Total & 72900.941 & 560 & & & \\
\hline
\end{tabular}

In order to determine among which average points of which sub-groups the differentiation in subject exists, double cells of each variable were composed. Single factor ANOVA results -performed in order to compare the averages of cells- were reviewed. 


\section{Result and discussion}

In the light of the findings obtained, it was determined that the effects of interaction of students' departments, their state of preparation for the exams and their academic averages gives rise to a significant difference among their assessment and evaluation course success scores. The results of single factor ANOVA -performed in order to compare the assessment and evaluation course score averages of double groups- indicate that the students studying on mathematics tutorhood and regularly getting prepared for the exams are significantly more successful in the assessment and evaluation course.

\section{References}

1. Alkharusi, H., Kazem, A.M. ve Al Musawai, A. Knowledge, Skills and Attitudes Of Preservice and Inservice Teachers in Educational Measurement. Asia-Pasific Journal of Teacher Education, (2011).

2. Ebel, R. L. Measuring Educational Achievement. Prentice Hall, Inc: Englewood Cliffs, New Jersey, (1965).

3. Ediger, Marlow. "Measurement/Evaluation Courses in Teacher Education" Education, 121(1), (2000).

4. İşgüzel, Ç. Uluslararası Öğrenci Değerlendirme Programı'nda (Pısa 2003) İnsan Ve Fiziksel Kaynakların Öğrencilerin Matematik Okur Yazarlığına Olan Etkisinin Kültürler Arası Karşılaştırılması. Yayımlanmamış Doktora Tezi, ODTÜ Uygulamalı Bilimler Enstitüsü, Ankara, (2006).

5. McMillan, J. H. Classroom Assessment: Principles and Practice for Effective Standarts Based Instruction. (4th ed). USA: Pearson Eduction, Inc., (2007).

6. Pektaş, S. Öğretmen Adaylarının Ölçme ve Değerlendirme Yeterlik Algılarının İncelenmesi. Yayınlanmamış Yüksek Lisans Tezi, Abant İzzet Baysal Üniversitesi, Sosyal Bilimler Enstitüsü, Bolu, (2010).

7. Stiggins, R.J. “Assessment, Student Confudence, and School Success", Phi Delta Kapan, 81(3), (1999).

8. Thorndike, R. L. ve Hagen, E. Measurement and Evaluation in Psychology and Education. (3rd ed). USA: John Wiley and Sons, Inc., (1969).

9. Yıldırım, İ. Akademik Başarının Yordayıcısı Olarak Gündelik Sıkıntılar ve Sosyal Destek. H.Ü. Eğitim Fakültesi Dergisi, 30, 258-267., (2006).

10. YÖK, Eğitim Fakültesi Öğretmen Yetiştirme Lisans Programı. (2007). http://www.yok.gov.tr/eğitim/oğretmen/öğretmenyetistirmelisansprogramlari. 